\title{
High Performance Liquid Chromatography for the Detection of Homozygotes and Heterozygotes of Niemann-Pick Disease
}

\author{
FIROZE B. JUNGALWALA ${ }^{(20)}$ AND AUBREY MILUNSKY \\ Department of Biochemistry and Human Genetics, Eunice Kennedy Shriver Center for Mental Retardation, Inc., \\ Waltham, and Department of Neurology and Pediatrics, Harvard Medical School, Boston, Massachusetts, USA
}

\section{Summary}

A method is developed for the detection of homozygotes and heterozygote carriers of Niemann-Pick disease type A by employing a high performance liquid chromatography (HPLC) technique for the measurement of sphingomyelin (SP) as well as for the assay of the enzyme sphingomyelinase (SPase) in skin fibroblasts and amniotic fluid cell cultures. A simple, less than 10-min, HPLC of the lipid extract of fibroblasts (about $2 \times 10^{6}$ cells) and measurement of the ratio of the area of SP peak to that of other phospholipids present in the cell-lipid extract show accumulation of SP in Niemann-Pick type $A$ fibroblasts compared to normal. The SPase assay was performed by HPLC measurement of the substrate SP before and after hydrolysis by the enzyme. By employing this technique, it was shown that cells from patients with Niemann-Pick disease type $A$ have less than $10 \%$ of the normal SPase activity, whereas the heterozygote carriers of this disease have about $50 \%$ of the normal activity.

\section{Speculation}

The HPLC method for the measurement of SP could be used for preliminary screening of a large number of samples suspected of Niemann-Pick disease. The diagnosis could be further confirmed by the actual SPase assay.

Niemann-Pick disease is characterized by SP lipidosis, foam cells in marrow, and hepatosplenomegaly. The accumulation of $\mathrm{SP}$ is caused by a deficiency of the enzyme SPase (2). This lysosomal enzyme splits SP into ceramide and phosphorylcholine. Various types of Niemann-Pick disease differ with respect to degree of SP storage in the visceral organs and the nervous system, age of onset and death, and severity of neurologic involvement (6). SPase is markedly reduced in the infantile form, type $A$. In type $B$, in which there is no neuronopathic involvement, large amounts of SP storage occurs in the visceral organs and the activity of SPase is about $10 \%$ of the normal level. In type $C$, the total SPase activity has been reported to be within normal limits (3) or about $50 \%$ of the normal (7). Some accumulation of SP is found in the visceral organs of type C patients. Callahan et al. (3) have detected by isoelectric focusing a specific deficiency of an isoenzyme of SPase in liver and brain from type $\mathrm{C}$ patients.

The current method for the assay of SPase requires the use of radiolabeled SP $(1,15)$. This material, although now commercially available, is expensive. In a recent method, an analog of SP (2-hexadecanoylamine-4-nitrophenylphosphorylcholine) has been employed (7). This material, however, is not a natural substrate for SPase. Other published methods involve quantitative paper chromatography of SP (4) or thin layer chromatographic analysis (TLC) of liberated ceramide and phosphoryl- choline (8) before and after enzymatic conversion. We have recently described a sensitive method for the separation and measurement of SP by HPLC (9). In this report we describe an application of this method for the assay of SPase, as well as for the measurement of accumulated SP in amniotic fluid cells and cultivated skin fibroblasts for the detection of homozygotes and heterozygotes of Niemann-Pick disease.

\section{MATERIALS AND METHODS}

\section{MATERIALS}

Bovine sphingomyelin obtained from Supelco, Bellefonte, PA was used as the substrate. The purity of the material was checked by TLC. Acetonitrile and methanol, the solvents used for HPLC, were of ultraviolet spectral grade (Burdick Jackson Labs., Muskegon, MI) and have cut-offs below $200 \mathrm{~nm}$. All other chemicals and reagents were of analytic grade.

\section{CELL CULTURE}

Methods for obtaining skin and amniotic fluid samples have been described previously $(12,13)$. The cells from these materials were cultured according to previously published procedures (13).

\section{ENZYME ASSAY}

SPase activity was determined with bovine SP in extracts of cultured skin fibroblasts or amniotic fluid cells as described below. The medium in which the cells were grown was washed away with phosphate-buffered saline, $\mathrm{pH} 7.4,10 \mathrm{mM}$. The cells were treated with $1 \mathrm{ml}$ trypsin, $0.25 \%$ in sodium citrate-buffered saline solution, $\mathrm{pH} 7.8,10 \mathrm{mM}$, per dish for $10 \mathrm{~min}$ at $37^{\circ}$. The cells were washed with phosphate buffered saline solution and centrifuged at $1000 \times g$ for $10 \mathrm{~min}$. The cells were rewashed as above and the pellet was frozen at $-20^{\circ}$.

Approximately $5-15 \times 10^{6}$ cells were homogenized in $0.5-1$ $\mathrm{ml} 0.1 \mathrm{M} \mathrm{KCl}$, Tris- $\mathrm{HCl}$ buffer, $0.05 \mathrm{M}, \mathrm{pH} 7.0$, containing $1.0 \%$ Triton X-100 (4). The homogenate was centrifuged for 1 $\mathrm{hr}$ at $50,000 \times \mathrm{g}$. The supernatant was carefully removed. The incubation mixture contained $0.2 \mathrm{mg} \mathrm{SP}(0.266 \mu \mathrm{mol})$, acetate buffer, $0.1 \mathrm{M}, \mathrm{pH} 5.2$, containing $0.25 \%$ Triton X-100 and an appropriate amount of the cell supernatant protein in a final volume of $0.2 \mathrm{ml}$. The incubation mixture before the addition of cell supernatant protein was sonicated in a Bransonic 220 sonicator bath for $5 \mathrm{~min}$ and incubated with the protein at $37^{\circ}$, with vigorous shaking for $4 \mathrm{hr}$, unless stated otherwise. After the incubation, $7.5 \mathrm{ml}$ chloroform-methanol $2: 1$ were added. The blank reaction mixture contained the same amounts of enzyme protein, SP, and buffer, but chloroform-methanol $(2: 1)$ was added immediately after the addition of enzyme protein. Each assay, including blanks, was performed either in duplicate 
or triplicate. The chloroform-methanol extract was washed with 0.2 vol $0.9 \%$ saline and the phases were separated by centrifugation. The lower phase was rewashed three times with a mixture of chloroform-methanol- $0.9 \%(\mathrm{w} / \mathrm{v})$ saline $(3: 48: 47$, by volume). The washed extract was then dried under $\mathrm{N}_{2}$ and the lipids were dissolved in $100 \mu \mathrm{l}$ ethanol. A suitable portion of the extract (usually 10-20 $\mu \mathrm{l}$ ) was then injected on a Micropak SI-10 (Varian, Palo Alto, CA) HPLC column, $50 \mathrm{~cm} \times 2.1 \mathrm{~mm}$ (internal diameter), essentially according to our previously published procedure (9). The column was developed with a mixture of acetonitrile-methanol-water ( $85: 21: 14$, by volume) at a flow rate of $1.5 \mathrm{ml} / \mathrm{min}$. The detection was at $203 \mathrm{~nm}$ with a Laboratory Data Control (Riviera Beach, FL) spectromonitor I coupled to a strip-chart recorder.

The amount of SP present in the blanks as well as in the incubated samples was determined by injecting known amounts of SP standard. The peak areas were measured by cutting the paper and weighing or by a Spectra Physics (Santa Clara, CA) computing integrator, Autolab System I. Each sample was injected at least twice and the response was averaged. The quantity of SP before and after the incubation was calculated. The specific activity of the enzyme is reported as nanomoles of SP hydrolyzed per mg protein per hr. The protein was assayed by the procedure of Lowry et al. (11).

\section{DETERMINATION OF SPHINGOMYELIN IN LIPID EXTRACTS}

The cell $\left(4-15 \times 10^{6}\right.$ cells $)$ pellets were warmed at $60^{\circ}$ for 15 min with $5 \mathrm{ml}$ chloroform-methanol $(1: 1, \mathrm{v} / \mathrm{v})$. The precipitated proteins were centrifuged and reextracted with $2.5 \mathrm{ml}$ chloroform. The combined lipid extracts were washed once with 1.4 $\mathrm{ml}$ saline and twice with $1.0 \mathrm{ml}$ theoretic upper phase (5). The extracts were dried and redissolved in $100 \mu \mathrm{l}$ ethanol. About $10-20 \%$ of the sample was injected onto the HPLC column as described previously. The response due to phosphatidylcholine (PC), phosphatidylethanolamine (PE) + phosphatidylserine (PS), and SP was measured by cutting the area of the corresponding peaks and weighing the paper or by a Spectra-Physics computing integrator Autolab System I. Each sample was injected at least twice and the response averaged.

\section{RESULTS}

\section{ASSAY OF SPHINGOMYELINASE}

A typical HPLC separation of the lipid extract of the incubation mixture is illustrated in Figure 1. The peak after the solvent front was due to PC which was extracted from the cell supernatants. The peak due to SP after the incubation was smaller than that before the incubation with normal cultured cell extracts. Since equivalent amounts of material were injected, the area of the PC peak remained the same before and after the incubation. This also indicated that PC was not hydrolyzed and that its degree of unsaturation was not altered during the incubation. The SP peak in Figure 1, $a$ and $b$ represents $53 \mathrm{nmol}$ and 24.1 nmol SP, respectively. The enzyme activity in the precipitates which remained after the extraction of the cells with Triton $\mathrm{X}$ 100 was negligible (4). The amount of SP present in the enzyme extracts of cultured cells was negligible as compared to added bovine SP and did not interfere in the assay.

Figure 2 represents the activity of the enzyme measured by varying the protein concentration of fibroblast cell extracts. The activity of the enzyme was linear up to about $350 \mu \mathrm{g}$ protein. The activity was linear up to $8 \mathrm{hr}$ with $180 \mu \mathrm{g}$ protein (Fig. 3).

Table 1 shows the activity of enzyme measured in the Triton X-100 extracts of skin fibroblasts and amniotic cells from fetuses or patients with Niemann-Pick disease and heterozygous carriers. In a typical experiment the incubation was for $4 \mathrm{hr}$ and the enzyme was extracted from $4-10 \times 10^{6}$ cells. The amount of protein used was about $0.1-0.3 \mathrm{mg}$. The assay was performed in duplicate at two different protein levels. The SPase activity in the enzyme extract of the cells of those with Niemann-Pick disease, type $\mathrm{A}$ was found to be $0-10 \%$ of the control values The control values varied between $108-208 \mathrm{nmol} / \mathrm{mg} / \mathrm{hr}$ between experiments. However, within the experiment, the variation was less. Such variations in control values of the SPase activity are also reported by others (7). The levels of SPase activity in the fibroblasts of the patient with Niemann-Pickf type $C$ was about $55-60 \%$ of the control values. Cultured skin fibroblasts obtained from carriers of Niemann-Pick type A had intermediate levels of SPase activity (Table 1 , experiment 4). Case 445 in experiment 4 (Table 1) was a possible heterozygous carrier since he was the brother of case 440 , a female obligate heterozygote. Case 445 showed about one-half the activity of SPase of the normal control and thus appeared to be a carrier of the gene for Niemann-Pick disease. The skin fibroblasts of the Niemann-Pick type $\mathrm{C}$ heterozygotes had SPase activity similar

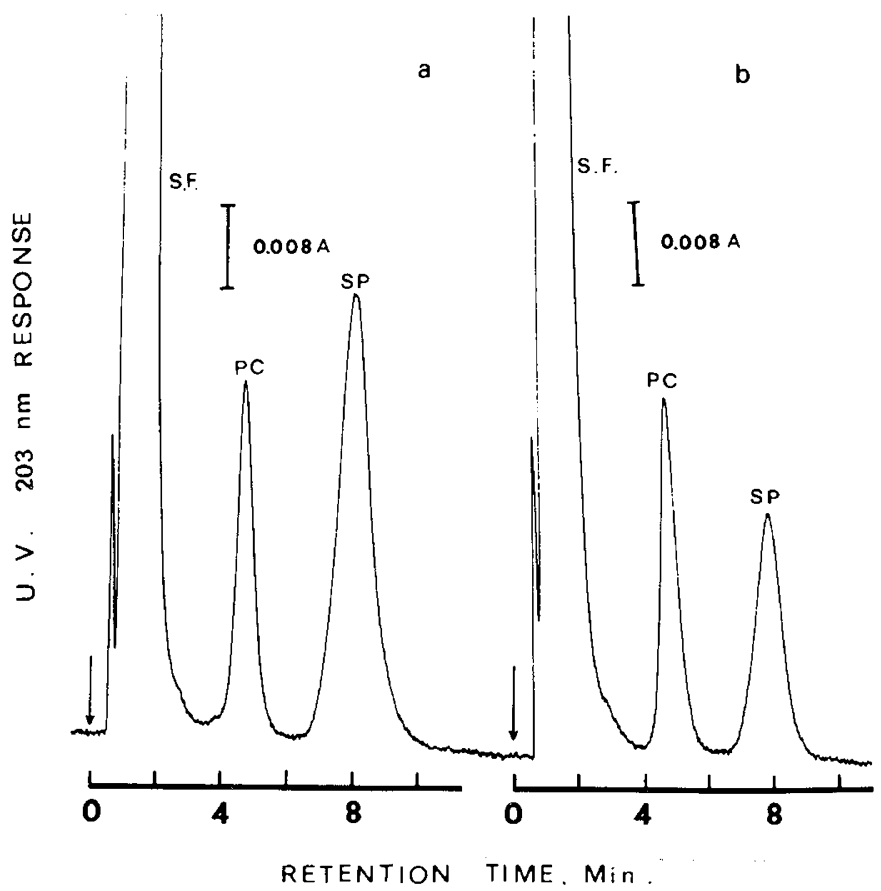

Fig. 1. The HPLC analysis of lipid extracts of incubation mixtures before $(a)$ and after $(b)$ incubation. The incubation mixture contained sphingomyelin and Triton X-100 extract of normal cultured fibroblasts. The amount of protein was $250 \mu \mathrm{g}$. Twenty percent of the total sample was injected in each case. Other conditions are described in the text. S.F., solvent front.

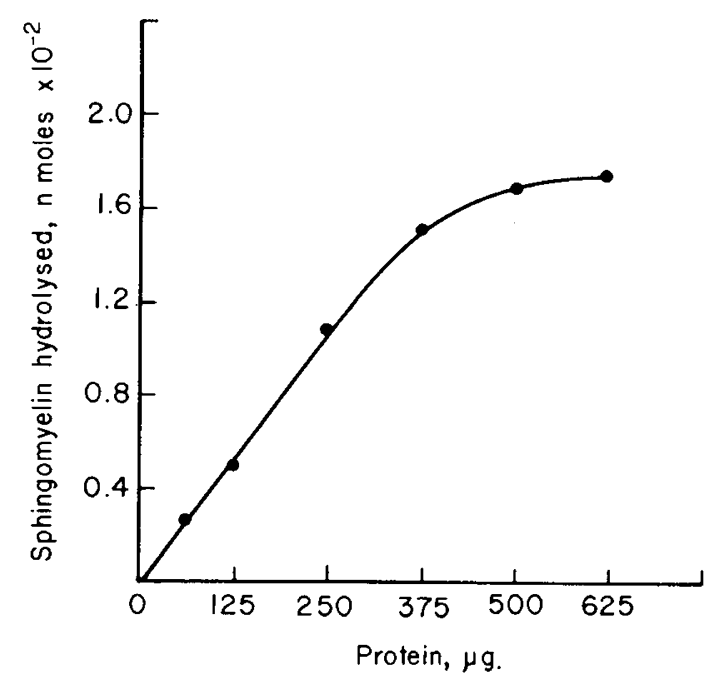

Fig. 2. Effect of varying amounts of protein on the hydrolysis of SP. Proteins from cultured skin fibroblasts were extracted and incubated as described in the text. 


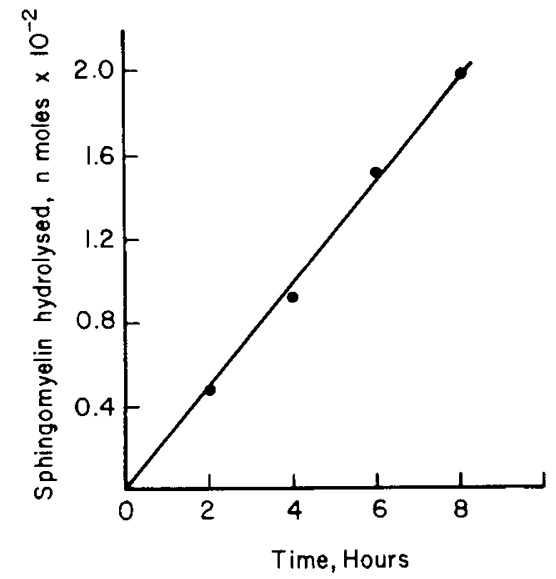

Fig. 3. Hydrolysis of SP by extracts of cultured skin fibroblasts as a function of time. Each incubation mixture contained $180 \mu \mathrm{g}$ protein. Other conditions were the same as described in the text.

Table 1. Specific activity of SPase in enzyme extracts of cultured skin fibroblasts and amniotic fluid cells

\begin{tabular}{|c|c|c|}
\hline \multirow[b]{2}{*}{ Diagnosis } & \multicolumn{2}{|c|}{$\begin{array}{l}\text { Sphingomyelinase activity, } \\
\mathrm{nmol} / \mathrm{mg} / \mathrm{hr}\end{array}$} \\
\hline & Average & Range \\
\hline \multicolumn{3}{|l|}{ Skin Fibroblasts } \\
\hline \multicolumn{3}{|l|}{ Exp 1} \\
\hline Normal control $(1202)^{1}$ & $108(3)^{2}$ & $100-118$ \\
\hline Niemann-Pick type A (439) & $4.8(2)$ & $0-9.6$ \\
\hline \multicolumn{3}{|l|}{$\operatorname{Exp} 2$} \\
\hline Normal control (1654) & $153.5(2)$ & $144-163$ \\
\hline Normal control (1202) & $121(2)$ & $114-128$ \\
\hline Niemann-Pick type A (1294) & $5.1(2)$ & $0-10.3$ \\
\hline Niemann-Pick type A (609) & $4.3(2)$ & $0-8.6$ \\
\hline \multicolumn{3}{|l|}{ Exp 3} \\
\hline Normal control (455) & $128(2)$ & $127-129$ \\
\hline Normal control (344) & $138(2)$ & $136-140$ \\
\hline Niemann-Pick type C (1001) & $75(2)$ & $72-78$ \\
\hline \multicolumn{3}{|l|}{$\operatorname{Exp} 4$} \\
\hline Normal control (1030) & $208(3)$ & $182-234$ \\
\hline Normal control (1654) & $180(3)$ & $166-192$ \\
\hline $\begin{array}{l}\text { Niemann-Pick obligate type A } \\
\text { heterozygote }(440)\end{array}$ & $76(2)$ & $67-86$ \\
\hline $\begin{array}{l}\text { Niemann-Pick obligate type A } \\
\text { heterozygote }(444)\end{array}$ & $93.5(2)$ & $85.6-101.4$ \\
\hline $\begin{array}{l}\text { Niemann-Pick suspected type A } \\
\text { heterozygote }(445)\end{array}$ & $101.5(2)$ & $98.3-104.6$ \\
\hline $\begin{array}{l}\text { Niemann-Pick heterozygote type } \\
\text { C (1560) }\end{array}$ & $187(2)$ & $177-197$ \\
\hline $\begin{array}{l}\text { Niemann-Pick heterozygote type } \\
\text { C (1561) }\end{array}$ & $175(2)$ & $173-177$ \\
\hline $\begin{array}{l}\text { Niemann-Pick heterozygote type } \\
\text { C (1562) }\end{array}$ & $177(2)$ & $172-182$ \\
\hline \multicolumn{3}{|l|}{ Amniotic fluid cells: Exp 5} \\
\hline Normal control (1664A) & $150(2)$ & $142-158$ \\
\hline Normal control (1664B) & $110.5(2)$ & $110-111$ \\
\hline Normal control (1662) & $144.6(2)$ & $137-152.3$ \\
\hline Normal control (1658) & $168(1)$ & \\
\hline Niemann-Pick type A (1653) & $8.1(3)$ & $2.6-10.9$ \\
\hline
\end{tabular}

${ }^{1}$ Represents case number.

${ }^{2}$ Represents number of assays performed.

to normal control subjects. The cultured fibroblasts from the Niemann-Pick cases, the heterozygotes, and some of the control subjects were also assayed for SPase using radioactive substrate

$5)$. The specific activity measured by this method was within

$\%$ of the values reported in Table 1 .

\section{DETERMINATION OF SPHINGOMYELIN IN LIPID EXTRACTS}

A typical HPLC separation of PE, PS, PC, and SP in the lipid extracts of fibroblasts from a normal control subject and that of a patient with Niemann-Pick type $\mathrm{A}$ is shown in Figure 4. PE and PS were eluted together in this system. It has been shown previously that the response measured at $203 \mathrm{~nm}$ for the phospholipids is primarily due to the double bond present in the molecule and the response varies with the degree of unsaturation (9). Thus, although the amount of PC (measured by lipid phosphorus after TLC separation (10)) was much higher than that of PE (ratio 4:1) in skin fibroblasts, the area of the HPLC peak for $\mathrm{PE}+\mathrm{PS}$ is about 1.4-2 times larger than that of $\mathrm{PC}$. This is because the amount of unsaturation in PE is greater. This ratio does not alter in the case of Niemann-Pick disease (Table 2).

SP constitutes about $8-10 \%$ of the total phospholipids in normal human fibroblasts. The area of the peak due to SP constitutes only about $3 \%$ of that of total phospholipids. This suggests that the amount of unsaturation in SP of fibroblasts is lower than that of other phospholipids. The relatively small peak observed for SP of the normal skin fibroblasts could thus be accounted for as due to low content and lower unsaturation. The ratio of area of the peak for sphingomyelin to that of PE + PS in normal skin fibroblasts varied from $0.048-0.058$ with an average ratio of 0.054 . This ratio was about $2-3$ times higher in the case of Niemann-Pick type A fibroblasts (Table 2). This ratio is slightly elevated in the case of Niemann-Pick type $C$ and in other unrelated disease fibroblasts. The average ratio of the area of the peak for SP to that of PC in normal skin fibroblasts was 0.09 . However, this ratio was about 2 times higher in the case of Niemann-Pick type A fibroblasts and only slightly higher in the case of Niemann-Pick type $\mathrm{C}$ and Niemann-Pick type A and $\mathrm{C}$ heterozygotes. This ratio also appeared to be slightly elevated in the case of other unrelated disease fibroblasts. These results suggest an accumulation of SP relative to other phospholipids in the fibroblasts of Niemann-Pick type A as compared to normal fibroblasts and demonstrate that type A cells can be identified with this convenient measure.

\section{DISCUSSION}

HPLC has become a useful tool for the rapid and efficient analysis of minute amounts of compounds which are not volatile. The analytic method described here for the detection of homozygotes (including in utero) and heterozygote carriers of Niemann-Pick type $A$ is shown to be possible in two different ways. A simple 10- to 12-min HPLC analysis of the lipid extract and measurement of the ratio of the area of the SP peak to that of either the PC or the PE + PS peak shows accumulation of SP in Niemann-Pick type A fibroblasts compared to normal and thus detection of such cases. However, detection of type $\mathrm{B}, \mathrm{C}$, or the heterozygotes of Niemann-Pick disease is not possible by this method since the characteristic ratio is not significantly different from control subjects and other possible diseases. It has been reported that the percentage of SP is generally increased in the brains of patients with Tay-Sach's disease, $\mathrm{GM}_{1}$-gangliosidosis, metachromatic leukodystrophy, and phenylketonuria, besides large increases found in the infantile and juvenile forms of Niemann-Pick disease (14). It is possible that the slightly elevated levels of the SP/PE and SP/PC ratios found in the fibroblasts of the patients with chondrodystrophy and the metachromatic leukodystrophy heterozygote could be due to the tendency of elevation of SP in tissues, which is also reflected in the fibroblasts in culture. The results obtained on the analysis of SP and other phospholipids of fibroblasts of Niemann-Pick type A are in agreement with those of Uhlendorf et al. (16). They reported on accumulation of SP 1.5-2 times the normal in the lipid extracts of skin and amniotic cell cultures of Niemann-Pick type A, analyzed by TLC and phosphorus determination. The direct HPLC method for the measurement of SP could be used for preliminary screening of large number of samples. The 


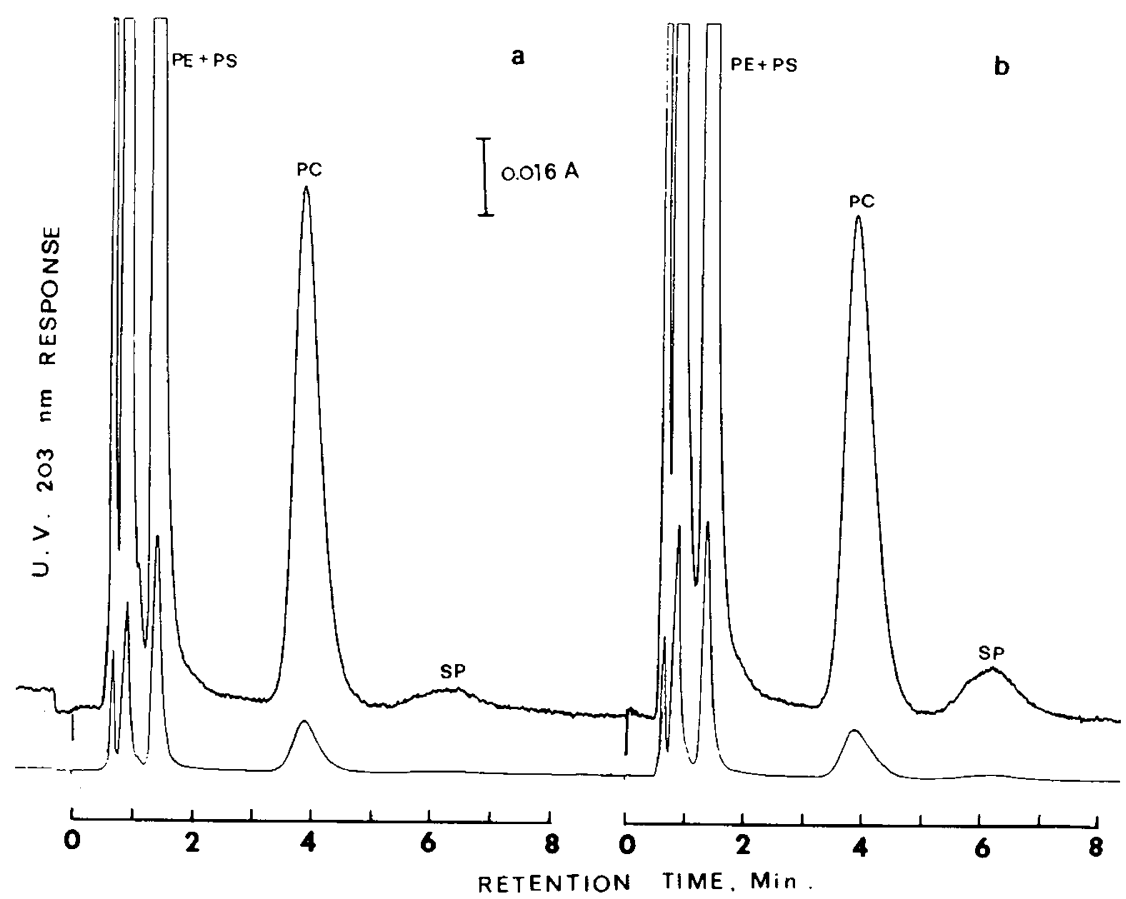

Fig. 4. The HPLC analysis of lipid extracts of human skin fibroblasts from $(a)$ normal control and $(b)$ Niemann-Pick type A. The chromatographic solvent was acetonitrile-methanol- $\mathrm{H}_{2} \mathrm{O}(75: 21: 14$, by volume). Other conditions for HPLC analysis are described in the text. S.F., solvent front. The lower chromatographic pattern in the figure was recorded at 10 times less sensitivity than the upper one.

Table 2. Analysis of $S P, P C$, and $P E+P S$ in lipid extracts of cultured skin fibroblasts by HPLC

\begin{tabular}{|c|c|c|c|c|}
\hline \multirow[b]{2}{*}{ Case no. } & \multirow[b]{2}{*}{ Diagnosis } & \multicolumn{3}{|c|}{ Ratio, ${ }^{1} \times 100$} \\
\hline & & $(\mathrm{PE}+\mathrm{PS}) / \mathrm{PC}$ & $\mathrm{SP} /(\mathrm{PE}+\mathrm{PS})$ & $\mathrm{SP} / \mathrm{PC}$ \\
\hline 1202 & Normal control & 151.5 & 5.7 & 8.65 \\
\hline 1650 & Normal control & 159.7 & 5.4 & 8.58 \\
\hline 1654 & Normal control & 222.0 & 4.82 & 10.7 \\
\hline 1028 & Normal control & 140.0 & 5.78 & 8.05 \\
\hline 541 & Metachromatic leucodystrophy, heterozygote & 152 & 6.91 & 10.5 \\
\hline 456 & Chondrodystrophy & 137 & 7.45 & 10.3 \\
\hline 1731 & Hypophosphatasia & 206 & 3.92 & 8.07 \\
\hline 439 & Niemann-Pick type A & 150.5 & 14.5 & 20.85 \\
\hline 609 & Niemann-Pick type A & 151.8 & 14.7 & 18.4 \\
\hline 1653 & Niemann-Pick type A & 145 & 9.0 & 13.1 \\
\hline 1294 & Niemann-Pick type A or B? & 142 & 6.8 & 9.42 \\
\hline 1001 & Niemann-Pick type C & 142 & 7.6 & 10.8 \\
\hline 440 & Niemann-Pick heterozygote type A & 102 & 7.2 & 7.1 \\
\hline 444 & Niemann-Pick heterozygote type A & 160 & 5.55 & 8.85 \\
\hline 1560 & Niemann-Pick heterozygote type $\mathrm{C}$ & 140 & 6.3 & 8.8 \\
\hline
\end{tabular}

${ }^{1}$ Average of two separate determinations.

diagnosis could be further confirmed by the actual SPase assay with Triton X-100 extract of the cells using the HPLC method It is also possible to detect the carriers of this disease by the SPase assay as performed with the application of HPLC. These diagnoses are possible for type A disease. The detection of type $\mathrm{C}$ disease and its heterozygotes is not possible by our method since fibroblasts of patients with type $C$ disease appear to have activity similar to those of type A heterozygotes, whereas type C heterozygotes have normal SPase activity.

The SPase assay is done with bovine SP, which has predominantly $\mathrm{C}_{24=1}(52 \%) \mathrm{C}_{18=0}(21 \%)$ fatty acid. It is not yet known whether the enzyme has preference for particular species of SP and whether there are any differences between normal and deficient cells. Many investigators, however, have reported that the fatty acid composition of the SP accumulating in various organs of the patients with type A disease is very similar to that of SP in the normal tissue (6). We did observe negligible but consistent, less than $8-10 \%$ of the normal, specific activity of SPase in type A disease fibroblasts and amniotic fluid cells, especially at a slightly higher protein concentration. Others have reported much lesser amounts of this activity in type A disease (7). The differences could be due to different substrates used in the method of assay of the enzyme.

\section{REFERENCES AND NOTES}

1. Brady, R. O.: Biochemical and metabolic basis of familial sphingolipidoses. Semin. Hematol., 9: 273 (1972)

2. Brady, R. O., Kanfer, J. N., Mock, M. B., and Fredrickson, D. S.: The 
metabolism of sphingomyelin II. Evidence of an enzymatic deficiency in Niemann-Pick disease. Proc. Natl. Acad. Sci. U. S. A., 55: 366 (1966).

3. Callahan, J. W., Khalil, M., and Philippart, M.: Sphingomyelinases in human tissues. II. Absence of a specific enzyme from liver and brain of NiemannPick disease type C. Pediat. Res., 9: 908 (1975)

4. DeRooij, R. E., Liem, K. O., Brouwer-Schipper, J. W., Husmann, G. G. F. M., and Hooghwinkel, G. J. M.: A method for the determination of sphingomyelinase activity. Clin. Chim. Acta, 59: 71 (1975).

5. Folch, J., Lees, M., and Sloane-Stanley, G. H.: A simple method for the isolation and purification of total lipids from animal tissues. J. Biol. Chem., 226: 497 (1957).

6. Fredrickson, D. S., and Sloan, H. R.: Sphingomyelin lipidoses: Niemann-Pick disease. In: J. B. Stanbury, J. B. Wyngaarden, and D. S. Fredrickson: The Metabolic Basis of Inherited Disease, Ed. 3, pp. 783-807 (McGraw-Hill Book Co., New York, 1972)

7. Gal, A. E., Brady, R. O., Hibbert, S. R., and Pentchev, P. G.: A practical chromogenic procedure for the detection of homozygotes and heterozygous carriers of Niemann-Pick disease. New Engl. J. Med., 293: 632 (1975).

8. Harzer, K., and Benz, H. U.: A simple sphingomyelinase determination of Niemann-Pick disease: Differential diagnosis of Types A, B, and C. J. Neurochem., 21: 999 (1973).

9. Jungalwala, F. B., Evans, J. E., and McCluer, R. H.: High performance liquid chromatography of phosphatidylcholine and sphingomyelin with detection in the region of $200 \mathrm{~nm}$. Biochem. J., 155: 55 (1976).

10. Jungalwala, F. J., Turel, R. J., Evans, J. E., and McCluer, R. H.: Sensitive analysis of ethanolamine- and serine-containing phosphoglycerides by highperformance liquid chromatography. Biochem. J., 145: 517 (1975).

11. Lowry, O. H., Rosebrough, N. J., Farr, A. L., and Randall, R. J.: Protein measurement with the Folin phenol reagent. J. Biol. Chem., 193: 265

0031-3998/78/1205-0655\$02.00/0

Copyright (c) 1978 International Pediatric Research Foundation, Inc.
(1951).

12. Milunsky, A.: The Prenatal Diagnosis of Hereditary Disorders (Charles C Thomas, Springfield, IL, 1973).

13. Milunsky, A., Spielvogel, C., and Kanfer, J. N.: Lysosomal enzyme variations in cultured normal skin fibroblasts. Life. Sci., 11: 1101 (1972).

14. Rouser, G., and Kritchevsky, G.: Human brain lipid composition changes with age and alterations in some pathological states: A new method of graphic analysis. Advan. Exp. Med. Biol., 19: 103 (1972).

15. Stoan, H. R., Uhlendorf, B. W., Kanfer, J. N., Brady, R. O., and Fredrickson, D. S.: Deficiency of sphingomyelin cleaving enzyme activity in tissue cultures derived from patients with Niemann-Pick disease. Biochem. Biophys. Res. Commun., 34: 582 (1969)

16. Uhlendorf, B. W., Holtz, A. I., Mock, M. B., and Fredrickson, D. S Persistence of a metabolic defect in tissue cultures derived from patients with Niemann-Pick disease. In: S. M. Aronson and B. W. Volk: Inborn Disorders of Sphingolipid Metabolism, Proceedings of the Third International Symposium on the Cerebral Sphingolipidoses, pp. 443-453 (Pergamon Press, New York, 1967).

17. Dr. R. H. McCluer is thanked for his interest in this project. Bernyce Perelle is thanked for technical assistance.

18. Dr. Firoze B. Jungalwala is supported by Research Career Development Award CA-00144.

19. This research was supported by USPHS Grants NS 10437 (F.B.J.); HD 04147, HD-05515, HD-09281 (A.M.); and GM-07015 (A.M.)

20. Requests for reprints should be addressed to: Dr. Firoze B. Jungalwala, Department of Biochemistry, E. K. Shriver Center, 200 Trapelo Road, Waltham, MA 02154 (USA)

21. Received for publication March 31, 1977.

22. Accepted for publication August 3, 1977. 